Research Report No. 60/2013

\title{
Transnational Legal Discourse: Reflections on My Time with the German Law Journal
}

Peer Zumbansen

Osgoode Hall Law School of York University, PZumbansen@osgoode.yorku.ca

Follow this and additional works at: http://digitalcommons.osgoode.yorku.ca/clpe

\section{Recommended Citation}

Zumbansen, Peer, "Transnational Legal Discourse: Reflections on My Time with the German Law Journal" (2013). Comparative Research in Law \& Political Economy. Research Paper No. 60/2013.

http://digitalcommons.osgoode.yorku.ca/clpe/302 


\section{OSGOODE}

OSGOODE HALL LAW SCHOOL

YOR K U N I VERSITY

\section{OSGOODE HALL LAW SCHOOL}

Comparative Research in Law \& Political Economy

RESEARCH PAPER SERIES

Research Paper No. 60/2013

Vol. 10, No. 2 (2014)

Transnational Legal Discourse: Reflections on My Time with the German Law Journal

German Law Journal, Vol. 14, No. 12 (2013)

Peer Zumbansen

Editors:

Peer Zumbansen (Osgoode Hall Law School, Toronto; Canada Research Chair in Transnational Economic Governance and Legal Theory - Editor in Chief)

Stephen Ji (Osgoode Hall Law School, Toronto -- Production Editor)

Comparative Research in Law \& Political Economy 
Osgoode CLPE Research Paper No. 60/2013

Vol. 10, No. 2 (2014)

\title{
Transnational Legal Discourse: Reflections on My Time with the German Law Journal
}

German Law Journal, Vol. 14, No. 12 (2013)

Peer Zumbansen

\begin{abstract}
:
This paper looks back at the first decade and a half of the German Law Journal, an online law review launched in 2000 and co-founded/co-edited by the author from 2000 until 2013. The refereed Journal, published monthly in English at www.germanlawjournal.com, began with case notes and essays on German, European and International high court decisions, and over time grew into a lively transnational forum for critical legal commentary. With a worldwide readership and authors ranging from law students to Supreme Court Justices, the Journal has long been both a launching pad for emerging scholars' writing careers and a vehicle for critical intervention from established scholars and seasoned practitioners. The GLJ provides a unique space for intellectual collaboration and thought exchange, for thematic symposia and timely engagement with newest legal-political developments. Tracing the evolution and publication record of the Journal since its start, the short essay highlights some of the GLJ's main contributions to transnational legal discourse, scholarship and legal education and emphasizes the significance of border-crossing scholarly collaboration, critical engagement and student mentoring.
\end{abstract}

\section{Keywords:}

Law review; transnational legal discourse; online publications; discussion forum; transnational law; EU law; international law; comparative law; legal education.

\section{Author:}

Peer Zumbansen

Professor of Law, Canada Research Chair

Osgoode Hall Law School, York University, Toronto

Senior Research Scholar, University of Michigan Law School, Fall 2013

Visiting Professor, Yale Law School, Spring 2014

E:Pzumbansen@osgoode.yorku.ca 


\title{
Reflections
}

\section{Transnational Legal Discourse: Reflections on my Time with the German Law Journal}

\author{
By Peer Zumbansen ${ }^{*}$
}

\section{A. Accounting}

By October, 2013, the German Law Journal, published monthly and available at no cost on the Internet - www.germanlawjournal.com - counted approximately 1593 publications, authored by approximately 1,450-1,500 authors. A journal project of such magnitude in itself could certainly not have been expected by its founders. ${ }^{1}$ Just as unlikely it would have seemed to them or anyone else, for that matter, that their little, bi-monthly email newsletter, originally entitled Momentaufnahme (Engl.: snapshot; French: glimpse d'oueil), would grow into a web-based, peer-reviewed legal periodical with more than 13.000 registered subscribers worldwide and an impressive journal ranking among existing international law reviews. ${ }^{2}$ If I only had a moment to express my thoughts on leaving the Journal, I would use it to express my immense gratitude to those whom I can never thank enough. My colleagues in this project, present and former members on the editorial board, and the authors, from near and far, many of whom we never had the fortune to meet in person despite an often vivid exchange of thoughts and ideas, as well as, of course, our readers throughout the years - it is to all of them that I owe thanks too comprehensive to measure. It is one thing to launch a journal, it is another for it to be read, sustained, shaped and encouraged over the span of almost fifteen years. The GLJ is what it is today because of the input it has received over all this time, and for that I am immensely grateful.

So, maybe, a few words are in order to provide some background to the emergence of the Journal, to its development and transformation as well as to its prospective outlook. Attempting neither a chronological or, by that measure, even remotely comprehensive or complete account of its existence until now, my brief remarks will merely try to

\footnotetext{
* Professor of Law, Osgoode Hall Law School, Toronto. State Exam (LL.B./JD equivalent), Frankfurt; Licence en droit, Paris-Ouest (Nanterre); LL.M., Harvard; PhD. (law), Frankfurt; Habilitation (Frankfurt). Co-founder/editor in Chief, German Law Journal, 2000-2013. E: PZumbansen@osgoode.yorku.ca

${ }^{1}$ The GL was founded in October 2000 by Russell Miller, a former U.S. criminal defense attorney and at the time a Robert-Bosch-Foundation Fellow at the Federal Constitutional Court of Germany, and by Peer Zumbansen, at the time a post-doctoral, senior research associate at Goethe University, Frankfurt and a clerk to FCC Justice, Dieter Hömig.

${ }^{2}$ According to a 2013 Google Scholar ranking, the GL ranks 9th among the most cited international law journals: http://scholar.google.com/citations?view op=top venues\&hl=en\&vq=soc internationallaw
} 
contextualize the GLJ in a number of ways. Such contextualization might offer a few insights into the miraculous ways in which circumstance and contingency, curiosity and enthusiasm as well as a collaborative spirit and commitment can bring about results that are in the end bigger than a sum of its parts.

\section{B. Beginnings}

The project began as a small, regular undertaking to comment, every other week, on new case law from both the German Federal Constitutional Court [FCC] (Bundesverfassungsgericht - BVerfG) and the Federal Court of Justice (Bundesgerichtshof $B G H)$. Such comments would be written in English and then distributed, via email, to readers in Germany and other countries. The newsletter would be comprised of anything between 10 and 20 pages of case notes - as well as book reviews or notes about legislative developments-formatted and paginated, and attached as a PDF file to an email, which we sent out twice a month. Given the wide range of topics that the newsletter and the Journal, which eventually grew from it, covered from the early months of its existence, the exact motivations and reasons for embarking on the project may not be obvious. The official motivation, one might say, was the recognition of an already sizable and continuously growing international interest in German constitutional jurisprudence, and the absence of a readily accessible medium - in both form and language - to meet this demand. Russell Miller, whom I met at the FCC in the fall of 2000, and I first contemplated a selective translation of cases coming out of the country's high courts. But, in light of the obvious limitations that the implied choice of cases as well as the unavoidable processes of authorizing the translation would have, we opted for a different approach. Every other week we would identify cases that we considered to be of interest to a transnational readership. Then we authored short case notes and commentaries that would constitute the core of our twice-monthly publication. In the attempt to make our newsletter more comprehensive, we included reports on new statutes and regulations, on significant appointments in the judiciary or on miscellaneous occurrences in the broader "legal culture." Under this latter rubric we published book reviews, conference reports, or, as in our very first issue, a commentary on the creation of Germany's first private law school Bucerius Law School in Hamburg. ${ }^{3}$

At first, we published these interventions without identifying the respective author for each piece, thinking that the main purpose of our newsletter was to offer a platform for pertinent and easily available information-in English-on developments in German jurisprudence and legal culture, rather than a vehicle to get our-Miller's and Zumbansen's - views out (as is, arguably, the nature of some of the leading law blogs these days).

\footnotetext{
${ }^{3}$ http://www.germanlawjournal.com/index.php?pagelD=11\&artID=5
} 
Sending the Momentaufnahme newsletter to friends, colleagues and to those scholars in Germany, Europe and elsewhere whom we considered to be potentially interested in this publication, we began receiving our first submissions "from outside" in late 2000 and early 2001, several months into the life of the project. Meanwhile, we were applying for funds from the Robert Bosch Foundation to create a more permanent, web-based platform, which would eventually go live in June 2001, not a year after the first dissemination of the newsletter. The newly minted, German Law Journal-Review of Developments in German, European \& International Jurisprudence began its life on the web with a symposium on the 50th Anniversary of the Federal Constitutional Court and featured contributions from a number of sitting FCC justices and other scholars. ${ }^{4}$ By the late summer 2001, to our astonishment, the GL already had a subscriber list of about 1,000 readers in different countries and was receiving contributions on a running basis. The editors found themselves in need to put the project on a sustainable footing and engaged in a research-intensive campaign to build a transnational editorial board, which would bring together early career scholars and law teachers during or at the end of their doctoral studies, who would be willing to give their time, intellectual energy and enthusiasm to a law journal project that was far from established, would demand a serious time commitment, and could very well turn out to be marginal. Adding to the occasional complaint, voiced predominantly by prospective German authors, why the GLJ did not offer honorariums for each publication, there were two other fundamental critiques, which were frequently made by older colleagues. These readers took issue with the fact that, on one hand, the Journal was both published (and thus accepting submissions) "only in English" and, on the other hand, it was available exclusively "on the Internet" without a printed, hard-bound version that could be found on the shelves of law school libraries or law firms. Rightly or wrongly, but ultimately undeterred, the editors decided to stick to English as the GL's exclusive language and to its online presence-despite occasional advances over the years from established domestic and international legal publishers who would have turned the Journal into a print medium. By early fall 2001, we had successfully assembled a transnational group of more than a dozen young editors, working in six countries and mostly without ever having met in person. Coordinating their work via email, we solicited or reviewed received submissions, exchanged ideas about new, important trends and developments or which new books merited reviews, which developments could inform symposia and special issues and which forthcoming judicial decisions were not to be "missed." Then, with the attacks of 11 September 2001, much, if not everything, about the Journal changed. In more than one way, that date resulted in resetting the time-count of the GL.

\footnotetext{
${ }^{4}$ http://www.germanlawjournal.com/index.php?pagelD=2\&vol=2\&no=9. Over the course of time, the GL published further scholarship from members of the FCC's bench.
} 


\section{Dialogue, Engagement and the Humility of Learning}

I was a Jean Monnet Fellow at the European University Institute, when a colleague at the Institute sent an email around to alert us of the breaking news of the fall of the first WTC tower. Like everyone else, we spent the next days and nights in a stupor realizing that, but not understanding how, the world had just irreversibly changed. About a week after the attacks we started discussing the idea of a Special Issue on "International Law and Politics after September $11^{\text {th }}$," for which we originally identified potential contributors by drawing on our respective and shared repositories of colleagues as well as other esteemed scholars who we knew to be working on international law in the broadest sense. As we saw that list grow and grow, we decided to just give it a try and to issue a "cold," that is generic and not personally addressed, call for papers for our Symposium through our email list. We received our first response mere minutes later, and after three weeks of feverish work, editorial comments going back and forth between us and our authors, the Journal was the first law review worldwide to publish a comprehensive survey of what were at that moment in time speculations, reflections and observations on the ways in which the attacks would likely set off a legal-political reaction the full dimensions of which would become visible only over an extended period of time. ${ }^{5}$

In many ways, the 9/11 symposium launched the GLJ's real presence-both as regards its online visibility and its recognition as a discussion platform for earnest and committed thought exchange on pertinent themes, important events, with a special interest in the fluidity of the boundaries that are thought to exist between law and politics, and determined to bridge domestic, comparative and international jurisprudence. With the 9/11 symposium, the Journal had manifestly begun to intervene into a sphere of scholarly, practical, as well as activist transnational discourse, which was increasingly and forcefully expanding through the Internet, through blogs, and through other modes of fast moving forms of online social media. The editors found themselves in the midst of a transnational discourse in which the GLJ appeared to have the potential of being a vehicle for a vibrant and extremely fast-moving, yet thoughtful and rigorous exchange of ideas, for legalpolitical commentaries and intellectual interventions. The symposium quickly attracted more and more new, unsolicited submissions and ultimately helped launch an increasingly engaged, transnational discussion among readers and authors. With no exception, all of the Journal's editors, including its original founders, had been making their own cautious steps into the world of academic publishing. They had all started out as tentative scholars who were trying to develop a somewhat recognizable voice, a standpoint, and an intellectual framework. Now, through the fast-paced work on the Journal, they found themselves "on the other side," no longer only developing and placing their respective scholarship in the hope that it might one day get published but playing the role of the ones who have the responsibility of making judgments about the quality of submissions, the

${ }^{5}$ http://www.germanlawjournal.com/index.php?pagelD=2\&vol=2\&no=16. 
adequacy of a scholarly intervention, its professional standard, its timeliness, and its potential as a publication that would be of interest to readers. Looking back, I have no doubt that the eventual realization of what it was that we were actually doing in this regard was one of the most important experiences during my work for the Journal. There was something very powerful and at the same time tremendously humbling about this role of editing scholarship, communicating with authors about specific aspects of their work as well as about the potential contribution that an essay could make to a debate, if it were to be revised in this way or that, if it were, for example, to lay out its central contentions more clearly while engaging more directly and diligently with the positions of other scholars participating in a larger discussion. Complementing this intensive work with authors was a demanding but immensely enriching and rewarding engagement with firsttime writers, most often young, early career researchers, who were either still in their law school studies, just at the beginning of their masters or doctoral work or who were working on positioning their scholarship during the transition phase between graduate studies and a first academic appointment. The GL, from its earliest days, became a forum for the publication of scholarship by second or third year law students along with that of established, world renowned legal scholars, judges or practitioners. In my view the fact that the GLJ functioned and published exclusively in English played a significant role in the transnationalization of many of our authors' scholarship, as the Journal was the launching pad for a great number of young authors who had never before written in English, and who now were given the opportunity (often enough experienced as a daunting challenge) to publish an essay, commentary or full-scale law review article that would be made available to a potentially global readership.

The motto that established itself before our eyes was one of a serious, uncompromised commitment to scholarly excellence that demanded a high degree of background research and exchange among editors as well as soliciting input from scholars outside of the board, on whom we began to rely over time for additional external anonymous peer review. In retrospect, there was a very particular type of energy and enthusiasm that both inspired and drove the editorial collaboration on the Journal in that respect. With time, editors began to spot and highlight notable developments, important new books, trends, trajectories and themes that would merit further exposition and engagement in the Journal's virtual pages. We became aware of where some of "the action" was and how the Journal might intervene in a debate. At the same time, our collaboration helped us muster the courage to formulate our own position and to put it "out there." Many of the Journal's editors became ardent observers of legal cultural developments around them, near and far, and with an editorial network spanning over a substantial number of countries it became possible to exchange ideas and thoughts on a symposium or important development within a short length of time. ${ }^{6}$

${ }^{6}$ The first editorial board convened members in Germany, the U.S., the UK, Italy, Belgium, and South Africa. 
When, in 2002, the GLJ convened a symposium on the recent trajectories of the global "war on terror," it had already become evident that the scope of that "war"-its implications and stakes - were significantly wider and more poignant than the problematic issues around the legality/illegality of a possible military attack on one of the countries suspected of hosting terrorists. As the contributions to the 2002 symposium made clear, the so-called "war on terror" had become deeply engrained in domestic legal and regulatory orders as the result of blanket legislation that-as in the examples of the U.S. P.A.T.R.I.O.T. Act or Canada's Anti-Terrorism Bill C-36 of fall of 2001-resulted in hundreds of minute changes in the countries' statutes and regulatory infrastructure. Working with our authors on that Special Issue we were encouraged to make conceptual and intellectual leaps to begin comprehending the theoretical and practical dimensions of the changes that were now under way on a global scale. The German Law Journal, with its visible online presence and benefitting from the input of wonderfully (crazily?) committed editors, became one of the places at which crucial, transnational debates could be facilitated, initiated or encouraged. No one, I think, on the editorial board, was left fully untouched by this experience, which would only intensify in the years to come.

\section{Domestic Places, Transnational Spaces}

And, despite all this, the GLJ was still that-the German Law Journal. Many times someone or other, inside or outside the project, ventured the idea of renaming the Journal. We eventually never did, but found that there was a deeper reason for keeping its original title despite its evolution into a vibrant, transnational legal periodical. Read some of the contributions to the symposia on Europe's "Darker Legacies" ${ }^{8}$ or "Bitter Memories," ${ }^{9}$ or about the German-American debate on "Critical Legal Thought," ${ }^{10}$ or former FCC justice Professor Wolfgang Hoffmann-Riem's comparative study on judicial review ${ }^{11}$ or Jürgen Habermas' poignant but beautiful reflections on the "Fall of a Monument." ${ }^{12}$ What emerges from these pages is a very unique focus on the embeddedness of legal discourse in a context that is always both domestic and transnational, historical and political. The GLJ had begun to offer a window for the world on developments within German legal culture, that might as well have been or are utterly idiosyncratic, limited or understandable really only "from within." But, by opening this window, the GLJ did more than just function as a translator or even exporter of "German" law. Rather, it presented an until-then unavailable

\footnotetext{
${ }^{7}$ Special Symposium: The World We (International Lawyers) Live in: Law and Politics One Year after 9/11: http://germanlawjournal.com/index.php?pagelD $=13 \& v o l=3 \&$ no $=9$

${ }^{8}$ http://germanlawjournal.com/index.php?pagelD $=13 \&$ vol=7\&no $=2$

${ }^{9}$ http://germanlawjournal.com/index.php?pagelD $=13 \&$ vol=6\&no $=2$

${ }^{10}$ http://germanlawjournal.com/index.php?pagelD=13\&vol=12\&no=1

${ }^{11}$ http://germanlawjournal.com/index.php?pagelD=11\&art|D=451

${ }^{12}$ http://germanlawjournal.com/index.php?page|D=11\&art|D=291
} 
opportunity to facilitate a transnational dialogue about the embeddedness and the contexts of legal cultures. In that regard, the contributions to the Journal were never just "domestic" or "comparative." Instead, in bridging inside accounts on case law, regulatory change, or legal discourse between different jurisdictions and between different ways of perceiving legal ordering, it became possible to recognize how law was undergoing change in many different forms, how law plays different roles in social transformation and how contextualized studies of legal change can help us gain a deeper understanding of the origins, drivers and directions of such change. ${ }^{13}$

Furthermore, on this side of the Journal's transnational spirit, there was always also already a distinctly transatlantic orientation in what the editors had hoped the Journal would embrace and nourish. As a testimony to such efforts, the Journal published a significant amount of comparative law scholarship, engaging with developments in both German/European and American law in a host of legal fields, authored by both emerging and established authors on both sides of the Atlantic. Furthermore, the Journal offered itself as a place where a debate could relatively easily and ever-more effectively be concentrated, enhanced and shaped. One such example was the symposium on Robert Kagan's ominous work on the cultural differences between the Venus-like, peace-loving, conflict-averse Europeans and the Mars-like, courageous, and risk-taking Americans. ${ }^{14}$ The symposium $^{15}$ was hosted by Heidelberg's Max Planck Institute for Comparative Public Law and Public International Law in the summer of 2002 and brought together a fine group of international scholars in law, political philosophy, history, and political science. Incidentally, the Heidelberg meeting was for many GLJ editors the first time they would actually meet in person. It was a most suitable venue for that first meeting, as the Heidelberg MPI had, from the Journal's beginning, served as one of the GLJ's most generous and appreciated anchors.

\footnotetext{
${ }^{13}$ See, e.g., Matthias Mahlmann, The Basic Law at 60 - Human Dignity and the Culture of Republicanism, 11 GERMAN LAW JOURNAL 9-32 (2010), available at: http://germanlawjournal.com/pdfs/Vol11No1/PDF_Vol_11_No_01_9-32_GG60_Mahlmann.pdf; Christian Joerges, Sozialstaatlichkeit in Europe? A Conflictof-Laws Approach to the Law of the EU and the Proceduralisation of Constitutionalisation, 10 GERMAN LAW JOURNAL 335-360 (2009), available at http://www.germanlawjournal.com/pdfs/Vol10No04/PDF_Vol 10 No 04 335360 SI Articles_Joerges.pdf; Stephan Leibfried, Christoph Möllers, Christoph Schmied and Peer Zumbansen, Redefining the Traditional Pillars of German Legal Studies and Setting the Stage for Contemporary Interdisciplinary Research, 7 GERMAN LAW JOURNAL 661-680 (2006), available at http://www.germanlawjournal.com/index.php?pagelD=11\&artID=750; Armin von Bogdandy, Positioning German Scholarship in the Global Arena: The Transformative Project of the German Law Journal, 10 GERMAN LAW JOURNAL 1295-1300 (2009), available at http://www.germanlawjournal.com/index.php?pagelD=11\&artID=1204, as well as Peer Zumbansen, Comparative Law's Coming of Age? Twenty Years after Critical Comparisons, 6 GERMAN LAW JOURNAL 1073-1084 (2005), available at http://www.germanlawjournal.com/index.php?pagelD=11\&artID=614.

${ }^{14}$ Robert Kagan, Power and Weakness. Why the United States and Europe see the World differently, 113 PoLICY REVIEW (June 1, 2002), online: http://www.hoover.org/publications/policy-review/article/7107

${ }^{15}$ http://germanlawjournal.com/index.php?pagelD=13\&vol=4\&no=9
} 
Similarly inspired by the Journal's embeddedness in transatlantic and European legalpolitical discourses, the GLJ appeared as one of the obvious fora for sustained, critical engagement with the European project. Looking at the Journal's long list of "Past Special Issues," 16 the Journal published almost ten symposia on questions of European integration, Europe's legal history, federalism, or constitutional reform. Each time the GLJ convened pertinent voices from scholars at different stages in their careers and with vastly different views and assessments. Complementing this dimension of the Journal, a number of symposia and a much higher number of individual contributions over the years have explored the relationship between national and international courts, both in the context of the EU and the ECHR. ${ }^{17}$ Again, complementing that line of investigation, the Journal published symposia on transnational human rights litigation and conflict of laws ${ }^{18}$ as well as a much cited special issue on the German Federal Constitutional Court's long awaited Lisbon judgment in 2009, ${ }^{19}$ which incidentally was the first journal symposium treatment of this important decision anywhere. Other symposia engaged with the international law scholarship of Jürgen Habermas; ${ }^{20}$ or the legal theoretical and philosophical legacies of Jacques Derrida; ${ }^{21}$ or offered a critical re-evaluation of Martti Koskenniemi's 1989 landmark work at the occasion of its reissue some 25 years later; ${ }^{22}$ or made available-for the first time online-the famous, long out-of-print, 1989 symposium between Bremen and Wisconsin scholars on the transatlantic dimensions of Critical Legal Studies; ${ }^{23}$ or convened a symposium on the Future of Kosovo; ${ }^{24}$ or explored the ever faster burgeoning field of Transnational Private Regulatory Governance; ${ }^{25}$ or provided the launching platform for the Max Planck's Institute path-breaking, large-scale research enterprises on "Public Authority" $^{26}$ and "International Judicial Institutions as Lawmakers." ${ }^{27}$ Another line of symposia focused on the work of individual scholars in administrative law and legal theory such as Karl-Heinz Ladeur; ${ }^{28}$ or in comparative constitutional law such as David Currie. ${ }^{29}$

${ }^{16}$ http://germanlawjournal.com/index.php?pagelD $=13$

${ }^{17}$ http://germanlawjournal.com/index.php?pagelD=13\&vol=12\&no=10

${ }^{18}$ http://germanlawjournal.com/index.php?pagelD=13\&vol=5\&no=12

${ }^{19}$ http://germanlawjournal.com/index.php?pagelD=13\&vol=10\&no=8

${ }^{20}$ http://germanlawjournal.com/index.php?pagelD=13\&vol=10\&no=1

${ }^{21}$ http://germanlawjournal.com/index.php?pagelD=13\&vol=6\&no=1

${ }^{22}$ http://germanlawjournal.com/index.php?pagelD=13\&vol=7\&no=12

${ }^{23}$ http://germanlawjournal.com/index.php?pagelD=13\&vol=12\&no=1

${ }^{24}$ http://germanlawjournal.com/index.php?pagelD=13\&vol=8\&no=1

${ }^{25}$ http://germanlawjournal.com/index.php?pagelD=13\&vol=13\&no=12

${ }^{26} \mathrm{http}: / /$ germanlawjournal.com/index.php?pagelD=13\&vol=9\&no=11

${ }^{27}$ http://germanlawjournal.com/index.php?pagelD=13\&vol=12\&no=5

${ }^{28}$ http://germanlawjournal.com/index.php?pagelD=13\&vol=10\&no=4 
Alongside, in between, before and after these-in themselves more visible, widely noted symposia-there have been gems, jewels, sparks of intellectual power, inspiration, rigor and courage, which are too many to enumerate in this context. The Journal's online, nocost $_{\text {archive }}^{30}$ is there, for you, to be mined and discovered.

\section{E. Attachments}

If I had to choose my "favorites" in the Journal's now impossibly long list of articles, essays and notes, I would have to recognize the very arbitrariness and inescapable injustice that would go along with making such a choice. But, that said, let me point to just a few among many events in the life of the Journal that made me feel a very special connection to the project we were trying to pursue. One such event is comprised of a number of essays on the political economy context of law. The essays I have in mind illustrate, in my view, the ways in which both lawyers who work in specific areas of law as well as those who research in the field of comparative legal studies should pay heed and remain open to insights from disciplines outside the law, in particular sociology, history, economics, political science as well as anthropology. This interdisciplinary dimension of legal research I found to be expressed very forcefully in GLJ publications dealing with legal harmonization and contentions of a global convergence of legal standards as well as the counter project expressed under the heading of the "varieties of capitalism." ${ }^{31}$ Betraying one of my own fields of scholarly interest (in corporate governance and comparative company law), I would highlight the just referred to pieces as examples of a type of legal research that is expressive of the changing contours in which domestic and comparative lawyers are researching today. In a world that is simply not structured by state-authored norms or judicial evocations alone but by an intricate interaction between international and domestic law, but also-in parallel hereto-by a legal pluralist web of intertwining hard and soft norms, official and unofficial norms, codes, best practices and recommendations, ${ }^{32}$ the task to identify what counts as "law" and what doesn't has long become a call for interaction between legal scholars and those in other disciplines.

\footnotetext{
${ }^{29}$ http://germanlawjournal.com/index.php?pagelD=13\&vol=9\&no=12

${ }^{30}$ http://germanlawjournal.com/index.php?pagelD=2

${ }^{31}$ See, e.g., Jürgen Hoffmann, Co-ordinated Continental European Market Economies Under Pressure From Globalisation: Germany's "Rhineland capitalism, 5 GERMAN LAW JOURNAL 985-1002 (2004), available at http://germanlawjournal.com/pdfs/Vol05No08/PDF Vol_05 No 08 985-1002_Legal_Culture Hoffmann.pdf; John Cioffi, Corporate Governance Reform, Regulatory Politics, and the Foundations of Finance Capitalism in the United States and Germany, 7 GERMAN LAW JOURNAL 533-562 (2006), available at http://germanlawjournal.com/pdfs/Vol07No06/PDF_Vol_07_No 06 533-562_Articles_Cioffi.pdf, as well as Reforming German Corporate Governance: Inside a Law Making Process of a Very New Nature Interview with Professor Dr. Theodor Baums, 2 GeRMAN LAW JouRnAL (2001), available at http://www.germanlawjournal.com/index.php?pagelD=11\&artID=43.

${ }^{32}$ See the Symposium on TPRG, supra, note 22.
} 
It is along those lines that a special place in my heart has always been reserved for the GLJ publications that deal with the way we train students to "think like a lawyer," in other words, our work on legal education. A highlight in that regard-and one of my fondest memories of my time with the Journal-is my work with a group of wonderful student editors at Osgoode Hall Law School in 2009 (where, a few years prior, I had obtained the permission to offer students editorial positions at the GLJ against credit, thus bringing the GLJ on an equal footing with the "official" law school review, the Osgoode Hall Law Journal) on a comprehensive, multi-country symposium on Transnational Legal Education. This symposium eventually amounted to more than 640 pages in print and brought together scholars from more than a dozen countries worldwide. ${ }^{33}$ The contributions to that symposium are widely regarded as a landmark contribution to a debate that is at the core of ongoing efforts not only to improve legal education and law school curricula, but-more significantly - to further enhance a reflection on the meaning of law and of being a lawyer. But, apart from that, the personally most impressive and memorable aspect of this work, perhaps, was the way in which the students at Osgoode took it upon themselves to identify the scholars they wanted to win as authors and contributors, and the way in which they did prior research on their scholarship that put them in a position, where they could with competence and confidence negotiate the contents of the prospective contributions. Finally, a wonderful aspect of that work was that it was possible to successfully solicit the support from the German Federal Ministry of Justice to bring the student editorial teams of my school and of Russell Miller's Washington \& Lee College of Law to Berlin for a twoday international symposium recognizing the 10th anniversary of the German Law Journal. The symposium, held jointly between the Ministry and the Faculty of Law of the Free University in Berlin, brought together scholars, but also judges, practitioners and students from far and wide for a series of inspiring engagements with the place of the Journal in both the domestic legal publishing world of Germany as well as its role in transnational legal discourse. ${ }^{34}$ It also allowed for a renewed discussion of some of the themes that had been central in the first decade of the Journal, including the importance (and, arguably, methodology) of comparative and transnational law, the political relevance of legal education reform, the European integration project as well as trends in international law, security law and legal theory. I think, for everyone present, the 2009 symposium marked an important and in many ways quite touching moment in the life of the Journal-and not only because the then Minister of Justice, Brigitte Zypries, gave a wonderfully engaged speech, in which she celebrated the success of the GLJ in creating a border-crossing intellectual, scholarly dialogue in law and legal culture.

\footnotetext{
${ }^{33}$ http://germanlawjournal.com/pdfs/Fulllssues/Vol 10 No 07.pdf

${ }^{34}$ http://germanlawjournal.com/index.php?pagelD=13\&vol=10\&no=10
} 


\section{F. Prospects}

In soliciting paper outlines from my students, I regularly ask of them to sketch, in no more than three, four sentences, where they see their particular topic of their paper to be in, say, the next five years. I specifically ask them not to wildly speculate but to try to make an informed and educated guess at what the future might hold for the question central to their particular research. Finding myself now in a comparable situation with the task of musing about where the GLJ might go in the future, I am experiencing a strange mix of emotions. On the one hand, I have a strong intuition that a project such as the GLJ has a number of parallel dimensions, some of which can be subtracted from the Journal without impacting its overall existence, while others are essential to its survival and flourishing in the future. On the other hand, as with most things in life, the GLJ in my experience was the result of an entirely unpredictable and in the end serendipitous encounter of a number of people at the right time in the right places. Eager to reach out and to intervene in a world that we found to be predominantly structured still by rigid rules of hierarchy and tradition, language conventions and elitist reproduction, we chose to take the prospects of the Journal-its likely failure or its improbable success-on our shoulders alone. Launching the Journal with an editorial board made up of young, absolutely unknown and inexperienced legal scholars we followed our instinct that in the long run scholars "with big names" would ultimately clog the project's arteries likely without ever making a real contribution to the daily life (and, work) of the Journal. Over time, this model proved "right," we might say, as the Journal enjoys considerable repute today and continues to be a vivid go-to place for interesting scholarship, commentary and exchange of ideas. But the passage of time has left its imprint on the project that still evokes reminiscences in the editors" memories of the first hour of the incredibly improvised, often feverish and insanely workintensive, engagement its publication and maintenance demanded from everyone involved. With the editors all having progressed in their respective career trajectories, the task for all involved in the GLJ today and tomorrow is to reflect on the method of renewal, transformation and sustainable growth. In my view, the Journal has made an important contribution to the legal discourse in that it has offered a space for serious editorial intellectual engagement amongst scholars in a wide range of legal fields and in a stupefying way across jurisdictional boundaries. Furthermore, there can be no doubt that the Journal has made an impression in the German legal culture, if only through its regular, constant presence in providing English-language commentary on ongoing pertinent developments. As the number of scholarly and judicial citations to GLJ scholarship as well as its classroom use continues to grow, its place in legal discourse and in legal education appears to have become considerably prominent. That is an achievement not in its own right, but in the way that it might speak to the changes that are underway in an increasingly transnational legal culture. As far as legal education reform is concerned, changes here seem to occur either in ad hoc adjustments or through slow, incremental shifts. An online forum such as the GLJ may continue to provide a space for earnest and critical, timely engagement among the different stakeholders of legal education - students, professors, administrators, bar associations and the judiciary. The GLJ's online presence 
along with the fact that every new issue as well as the Journal's entire archive is freely available online, has reportedly made it an attractive source of information and commentary around the world. We are certainly grateful and humbled by the acclaim we have received over the years from scholars, teachers and judges in more than 90 countries around the world, emphasizing the value embodied in this particular resource. Whether or not an online legal periodical can over the course of time continue to offer an alternative or viable complement to the ever faster growing media in forms of blogs and other internet discussion fora, is an open question. What the future may hold for the GLJ depends to the largest degree on those who carry it forward and on their willingness to keep it a vibrant, open space for rigorous transnational legal discourse. 